\title{
NATURE AND BASIC PROBLEMS OF NON- CONVICTION-BASED CONFISCATION IN THE UNITED STATES
}

Stefan D. Cassella

Stefan D. Cassella é ex-assistente do Procurador Geral dos Estados Unidos especializado em processos visando à recuperação de ativos e lavagem de dinheiro tendo atuado durante 30 anos. Sua firma, Asset Forfeiture Law, LLC, provê treinamento e assistência jurídica para agências de persecução que trabalhem com perdimento de bens e lavagem de dinheiro tanto em nível local, estadual, federal bem como no estrangeiro.

\begin{abstract}
This report discusses the goals that asset forfeiture is intended to serve in the federal criminal justice system, the types of property that are subject to forfeiture, and the procedures that are used to initiate, litigate, and conclude asset forfeiture cases. With respect to procedure, its focus is on nonconviction-based (NCB) forfeiture, and especially on the safeguards that protect the property interests and due process rights of property owners.
\end{abstract}




\section{NATUREZA E PROBLEMAS BÁSICOS ENVOLVENDO A EXTINÇÃO CIVIL DO DOMÍNIO NOS ESTADOS UNIDOS.}

\section{RESUMO}

Este artigo discute as metas que o confisco de ativos pretende cumprir no sistema de justiça criminal federal, os tipos de propriedade que estão sujeitas a confisco e os procedimentos que são utilizados para iniciar, litigar e concluir casos de confisco de ativos. No que diz respeito ao procedimento, seu foco está na caducidade não baseada em condenação (NCB) e, especialmente, nas salvaguardas que protegem os interesses da propriedade e os direitos processuais dos proprietários. 


\section{INTRODUCTION}

The United States has a robust asset forfeiture program. In each of the last five fiscal years, federal law enforcement agencies have recovered more than two billion dollars in assets through criminal and nonconviction-based asset forfeiture actions. ${ }^{1}$ Most of those recoveries were based on violations of the federal criminal law. The remainder involved assets found in the United States that were derived from violations of foreign law.

In cases involving victims, the recovered assets are applied to victim restitution; in the remaining cases, the money is distributed among the federal, state and local law enforcement agencies, and is used for law enforcement training and equipment and to defray investigative and litigation expenses. In cases where the assets were derived from a violation of foreign law, the recoveries are shared with the foreign states pursuant to existing Mutual Legal Assistance Treaties (MLATs).

This report discusses the goals that asset forfeiture is intended to serve in the federal criminal justice system, the types of property that are subject to forfeiture, and the procedures that are used to initiate, litigate, and conclude asset forfeiture cases. With respect to procedure, its focus is on non-conviction-based (NCB) forfeiture, and especially on the safeguards that protect the property interests and due process rights of property owners.

\section{AIMS AND GENERAL CHARACTERISTICS}

Roughly half of the assets recovered through the federal asset forfeiture program are recovered as part of the defendant's sentence following a successful criminal prosecution, and the remainder are recovered in NCB forfeiture actions. In both cases, the goals of the forfeiture proceeding are the same.

\footnotetext{
1 The data from the Justice Department's Assets Forfeiture Fund are published at https://www.justice. gov/afp. It shows deposits for the FY13 - FY16 totaling the following amounts, respectively: \$2.1 billion, $\$ 4.5$ billion, $\$ 1.6$ billion, $\$ 1.9$ billion. The variation is due to the inclusion two extraordinarily large recoveries in FY14. There is also a smaller Treasury Fund that collects receipts from cases handled by the Department of Homeland Security and the Department of the Treasury. Receipts into the Treasury Fund are typically one-third of those into the DOJ Fund. The total federal forfeiture receipts may be computed by aggregating the two Funds. For FY17, the DOJ fund deposited\$1.64 billion, of which $\$ 480$ million was derived from uncontested NCB forfeitures, $\$ 580$ million from contested NCB forfeitures, and \$590 million from criminal forfeitures. A chart setting forth the DOJ statistics from FY07 through FY16 graphically is appended as Attachment A.
} 
The Supreme Court of the United States summarized the goals of the federal asset forfeiture program in Kaley v. United States, $134 \mathrm{~S}$. Ct. 1090, 1094 (2014). Forfeiture, the Court said, serves to punish the wrong-doer, deter future illegality, lessen the economic power of criminal enterprises, compensate victims, improve conditions in crime-damaged communities, and support law enforcement activities such as police training. In short, the goals of asset forfeiture are the goals of criminal law enforcement generally - punishment, deterrence and incapacitation plus several additional objectives that forfeiture is uniquely designed to achieve.

\subsection{Punishing the wrongdoer}

As most criminal prosecutors know, many criminals care more about keeping the money and other assets derived from their particular crime than they do about serving time in jail. ${ }^{2}$ Accordingly, to punish the defendant, the prosecutor seeks not just to put him jail, but to take away the fruits of his crime.

In the prosecutor's view, it makes no sense to prosecute a person for fraud and to let him keep the fraud proceeds, or to let the drug dealer keep the assets that he acquired with the revenue from his illicit acts. Accordingly, prosecutors generally insist that the defendant's agreement to forfeit the proceeds of his crime be included in any negotiated settlement of a criminal case. Often that will entail requiring the defendant to pay a judgment equal to the proceeds he received, even if he has spent the money, and even if he has reimbursed the victim.

\subsection{Deterring other wrongdoers}

The second goal of the criminal justice system is deterrence. In most federal criminal cases, the defendant's objective in committing the crime is to make money. If the defendant does not get to keep the money, there will be less incentive for the next person to commit the same offense. Conversely, allowing criminal defendants to retain the proceeds of their

2 A fictional example, often cited in law enforcement training conferences in the US, is provided by the Netflix television series Breaking Bad, in which the main character, Walter White, a chemist who produces vast quantities of high-quality methamphetamine for drug traffickers, goes to great lengths to launder and shield the proceeds of his crime from law enforcement - ultimately at the cost of his life - to preserve the money for his family. 
crimes would likely provide an incentive to others to commit similar offenses despite the risks involved - precisely the opposite of the deterrent effect that law enforcement is intended to achieve.

\subsection{Taking away the tools of the trade and the economic resources}

Third, asset forfeiture serves as a form of incapacitation. Obviously, firearms are confiscated so that they cannot be used to commit other gun-related crimes in the future. Similarly, the Government uses asset forfeiture to prevent the drug dealer from using an airplane to smuggle more drugs, or the child pornographer from having another chance to use his computer to distribute more illegal images.

In a broader sense, however, the Government uses asset forfeiture to close off the avenues that are used to commit crimes. Using NCB forfeiture to recover the proceeds of kleptocracy provides a good example. If the corrupt leaders of other countries are using the US financial system to launder the money they have stolen from their treasuries, and if they are hiding or investing the money in US-based assets, the forfeiture of those assets under the money laundering laws closes the door on that process and makes it more difficult for future thefts to succeed.

\subsection{Disrupting the organization}

Forfeiture as a form of incapacitation applies to organizations just as it applies to individuals. Money is the glue that holds organized criminal enterprises together; they must recycle the money to keep their illegal scheme going. Without the constant flow of money, the criminal conduct would come to a halt.

For example, it is often said that it is harder for a drug organization to replace the money that is earned from selling drugs than it is to replace the drugs themselves, and that forfeiting the money therefore does more to interrupt the drug trafficking cycle than any number of arrests.

The same is true for organizations engaged in wildlife trafficking: seizing the money flowing from Asian markets back to the poaching enterprises is a far more effective way of suppressing the wildlife trade than arresting the low-level operatives in Africa who possess nothing more than a truck and gun.

Most important, seizing money destined for sanctioned countries 
like North Korea and Iran disrupts their ability to evade those sanctions, and seizing money intended to be used to finance terrorism has the potential of saving countless lives.

\subsection{Returning money to the victims}

Beyond punishment, deterrence and incapacitation, forfeiture serves other purposes. Forfeiture, for example, is a more effective way of recovering money for victims than ordering the defendant to pay restitution. As the Court of Appeals said in United States v. Blackman, 746 F.3d 137, 143 ( $4^{\text {th }}$ Cir. 2014), "The Government's ability to collect on a [forfeiture] judgment often far surpasses that of an untutored or impecunious victim of crime . . . Realistically, a victim's hope of getting paid may rest on the Government's superior ability to collect and liquidate a defendant's assets" under the forfeiture laws.

Accordingly, in the federal forfeiture program, victims always come first. If there are victims, the forfeited money is used to reimburse the victims, unless the defendant has the resources to pay the victims himself. It is only if there are no victims, or the defendant is able to pay them himself, that the money may be used for training, equipment and other law enforcement purposes.

\subsection{Protecting the community}

Obviously, if there are fewer guns on the street, the community is safer, but forfeiture protects the community in other ways as well. It prevents criminals from acquiring controlling interests in industries, dominating markets (e.g. the upscale housing market), or acquiring wealth used to corrupt public officials. In white collar cases, recovering money from corrupt corporate executives or public officials gives law enforcement the opportunity to convince the community that criminals will not be allowed to profit from their crimes; that the law treats everyone equally; and that the powerful and well-connected cannot act with impunity.

Moreover, forfeiting the proceeds of crime ensures that the economic playing field is level, so that people trying to run businesses honestly do not have to compete with those who have access to untaxed capital from illegal sources. 


\subsection{Recycling the money}

Finally, forfeited funds can be shared with state and local law enforcement and used to fund law enforcement programs. Some forfeited property can also be put into official use or handed over to community organizations. This, however, has become the controversial side of the asset recovery program; what seems to law enforcement to be an appropriate use of recovered criminal assets strikes critics as "policing for profit" that is, seizing and forfeiting assets not to achieve some legitimate law enforcement objective, but to provide the law enforcement agency with revenue needed to fund its operations.

\section{SUBSTANTIVE REQUIREMENTS: WHAT PROPERTY IS SUBJECT TO FORFEITURE}

In the United States, in contrast to most other countries, asset forfeiture does not apply universally to all crimes, either foreign or domestic. To the contrary, the legislature has enacted a different forfeiture provision for each federal criminal offense and has granted only limited authority to recover the proceeds of certain foreign crimes. As a result, there are some crimes for which the Government can recover the proceeds of the offense, others for which it can recover the property used to commit it, and others for which it cannot recover any property at all.

Moreover, while criminal forfeiture is available for any crime for which NCB forfeiture is authorized, the reverse is not true: there are some crimes for which criminal forfeiture is authorized but NCB forfeiture is not. Accordingly, the prosecutor or investigating law enforcement agent must look to the applicable statute to determine what property, if any, can be recovered in connection with a particular offense, and what procedure is available for recovering it.

Moreover, the asset forfeiture statutes are scattered all over the US Code; there is no single statute that applies to all crimes. Thus, prosecutors are required to keep an index that cross-references each federal offense with the forfeiture provision that applies to it.No one thinks this is an optimal situation that any other country should emulate. 


\subsection{Proceeds}

For most crimes, the Government can recover the proceeds of the offense, and in most cases, what constitutes the proceeds of the offense is fairly obvious: it is whatever the defendant acquired - or was able to retain - as a result of the criminal act. If he sold drugs, the money he received for the drugs is the proceeds; if he robbed a bank, committed fraud, or took a bribe, the money from the bank or from the fraud victim or the bribe payment would be the proceeds.

The scope of the term "proceeds," however, can be quite broad and can include property acquired indirectly. Thus, to determine what property is forfeitable as the proceeds of an offense, the courts generally apply a "but for" test, reasoning that whatever the defendant would not have but for having committed the offense constitutes the proceeds of his crime.

For example, the salary that a defendant would not have received but for his unlawful conduct in committing securities fraud could be forfeitable as "proceeds" of that offense. ${ }^{3}$ Or the interest on the investment account that the defendant would not have earned but for his having opened the account with someone's stolen identity could be the proceeds of the identity theft. ${ }^{4}$ Indeed, under the "but for" test, an entire business, and all of its revenue and assets, may be subject to forfeiture if the business would not exist but for the investment of criminal proceeds to start the business or to keep it going. ${ }^{5}$

In addition, "proceeds" includes not only property that the defendant obtained as a result of the offense, but property that the offense allowed him to retain as well. For example, if the defendant is able to have a debt reduced by paying a bribe, the money saved by the reduction of the debt may be considered the proceeds of the bribe. ${ }^{6}$

In federal law, "proceeds" generally means "gross proceeds," not net profits, but that is not always true. While most courts hold that drug dealers and others engaged in inherently unlawful conduct cannot deduct the cost of doing business, the ability to deduct such costs in other cases is not so clear.

3 United States v. Shabudin, 701 Fed. Appx. 599 (9th Cir. 2017).

4 United States v. Cekosky, 171 Fed. Appx. 785, 787-88 (11th Cir. 2006).

5 United States v. Warshak, 631 F.3d 266, 329-330 (6th Cir. 2010);United States v. Smith, 749 F.3d 465, 488-89 (6 $6^{\text {th }}$ Cir. 2014).

6 United States v. Esquenazi, 752 F.3d 912, 931 (11th Cir. 2014). 
Suppose, for example, that someone obtains a contract to build a road by bribing the contracting officer, but actually builds the road. Is all of the money that he received on the contract subject to forfeiture on the ground that but for having paid the bribe, the defendant would never have gotten the contract? Or is he entitled to deduct the costs incurred in building the road? The courts in the United States are divided on that issue. ${ }^{7}$

\subsection{Facilitating Property}

For some federal crimes - but unfortunately not for any foreign crimes - the Government can recover what is commonly called "facilitating property."Such property can be recovered in drug cases and cases involving child pornography, for example, but not in most white-collar cases such as fraud or public corruption. Whether a given forfeiture statute provides for the forfeiture of facilitating property is usually a matter of historical accident rather than the result of any considered policy decision.

Generally, facilitating property is defined as any property that made the crime less difficult to commit, or more or less free from obstruction or hindrance. ${ }^{8}$ Such a broad definition obviously leads to issues regarding the proportionality of the forfeiture to the gravity of the offense, but the courts have addressed that issue in two ways.

First, as a matter of statute, federal law provides that there must be a "substantial connection" between the property and the offense, which the courts define as meaning a connection that is "more than incidental or fortuitous." Thus, if the connection between the property and the offense is too tangential, the forfeiture will not succeed, even if the property did facilitate the commission of the offense in some minor way. ${ }^{10}$

Second, even if property satisfies the substantial connection test, the court may require that the forfeiture be mitigated if the magnitude of the forfeiture - as measured by the value of the property and other factors

7 CompareUnited States v. Martin, 2014 WL 221956, *5 (D. Idaho Jan. 21, 2014) (contractor who obtains a Government contract by falsely claiming eligibility for a program for disadvantaged businesses must forfeit the net profits, not the gross proceeds, of the fraudulently-obtained contracts)with United States v. Pinson, 2015 WL 1578726 (D.S.C. Apr. 9, 2015) (defendant who would not have submitted any invoice to the Government but for an illegal agreement that allowed him to submit inflated invoices must forfeit gross proceeds without credit for services actually performed).

8 United States v. Huber, 404 F.3d 1047 (8th Cir. 2005).

918 U.S.C. $\S 983(c)(3)$ (requiring a "substantial connection" between the property and the offense).

10 United States v. One 1989 JaguarXJ6, 1993 WL 157630, *3 \& n.2 (N.D. Ill. May 13, 1993). 
- would be "grossly disproportional to the gravity of the offense." 11 That issue is discussed below in the context of the Constitutional limits placed on forfeiture by the application of the Bill of Rights.

\section{PROCEDURES AND THEIR SAFEGUARDS: WHO INVESTI- GATES THE CASES? WHAT COURT DO THEY GO TO?}

The United States is a common law country, which means that unlike the system in civil law jurisdictions, federal courts and judges take no part in the investigation and prosecution of criminal cases. The cases are investigated by law enforcement agencies and are presented in court by federal prosecutors.

All asset forfeiture investigations are considered criminal investigations; when the investigation is complete, the prosecutor decides whether to seek the forfeiture of assets as part of the defendant's sentence in a criminal case or in a separate NCB forfeiture action. In either case, the purpose of the forfeiture is the same: to achieve one or more of the goals described earlier in Part II.

There is no distinction between criminal and civil courts in the federal judicial system: All federal judges can and do hear both criminal and civil cases, including criminal and NCB asset forfeiture cases. Accordingly, whether the prosecutor decides to pursue the forfeiture criminally or otherwise, the forfeiture action is filed by the same prosecutor in the same court.

Asset forfeiture investigations are generally initiated by one of the federal law enforcement agencies. Each agency has areas of expertise and responsibility. For example, the FBI investigates fraud and corruption cases; the IRS investigates tax and money laundering cases; the DEA investigates drug cases; HSI investigates smuggling cases, and so forth. The same agencies investigate the cases in the same way whether the case will ultimately be pursued as a criminal forfeiture or as an NCB forfeiture action.

The investigative tools available to the agents include physical and electronic surveillance, witness interviews, subpoenas requiring the compulsory production of records (including bank records), searches and seizures, and calling witnesses before an investigative grand jury. At the investigative stage, the same tools are available, and the same rights against

11 United States v. Bajakajian,524 U.S. 321, 323 (1998);18 U.S.C. § 983(g). 
self-incrimination and unreasonable searches and seizures apply, whether the prosecutor ultimately decides to pursue the forfeiture case criminally or civilly. Indeed, in most cases, the prosecutor will not have made any decision as to the method of forfeiture until the investigation is complete. ${ }^{12}$

When the agency feels that the investigation has reached a certain point, the agents present it to a federal prosecutor, who may say that the case is ready to file in court or may suggest that some additional investigation is required.It is the agency's responsibility not only to investigate the crime and to gather the evidence needed to prove it, but also to locate the assets that were derived from the crime or that were used to commit it, and to assemble the evidence that will be needed to establish that connection in court. Thus, while it is a rare occurrence, a prosecutor may decide that a case is not ready to file because although the agents have completed their investigation of the underlying crime, they have not completed their investigation of the assets subject to forfeiture.

When the prosecutor decides that the case is ready, he or she will decide if the Government will attempt to recover the assets as part of a criminal case or in an NCB action separate from any criminal prosecution. Either way, when the case goes to court, the Government must prove two things: that a crime was committed, and that the property that the Government wants to recover was derived from or was used to commit that crime. And either way, the accused - or the property owner - has the right to have the forfeiture determined by a jury.

In the end, if the Government is successful, the court will make an order forfeiting title to the property to the United States.

In sum, judges, law enforcement officers, and policy makers in the United States take the following view of asset forfeiture: the object of the entire process - including the investigation and prosecution - is the forfeiture of assets; its purpose is to achieve the goals described above, including punishment, deterrence, incapacitation, and victim restitution; and the method by which these purposes are achieved - criminal forfeiture as part of a criminal prosecution or a separate NCB forfeiture action is a strategic choice made by the prosecutor depending on the facts and circumstances of the case. The considerations the prosecutor uses in determining which route to take are discussed below.

There are always exceptions, of course; some cases are more

12 In the rare case in which the prosecutor knows from the outset that a criminal prosecution will not be possible, certain investigative tools, such as the use of an investigative grand jury, may not be available. 
complicated than others. But typically, an asset forfeiture case can be resolved either criminally or civilly in about a year.

\subsection{Criminal forfeiture procedure}

As already mentioned,federal law in the United States allows assets derived from or used to commit a criminal offense to be recovered in either of two ways:as part of the defendant's sentence following his conviction in a criminal case, or in a separate non-conviction-based ("NCB" or "civil") forfeiture proceeding.

Criminal forfeiture procedure is reasonably straightforward:if the defendant is convicted, the court orders him to forfeit the proceeds of his crime and the property that he used to commit it. The determination that a given asset is subject to forfeiture is made by the same jury that rendered the guilty verdict at trial, or if the defendant waives the jury, by the court as part of the sentencing process. ${ }^{13}$ While the guilt of the defendant must be established beyond a reasonable doubt, the forfeitability of the property is determined by a balance of the probabilities. ${ }^{14}$ Moreover, because the forfeiture determination is part of the sentencing process, hearsay is admissible at the forfeiture hearing. ${ }^{15}$

In contrast to other countries, the United States has not embraced the concept of extended confiscation. To the contrary, criminal forfeiture is limited to the assets derived from or used to commit the offense for which the defendant was convicted. The prosecutor may be able to expand the scope of forfeiture under this rule by seeking to convict the defendant of a conspiracy or other overarching crime such as a "scheme to defraud" instead of charging only a discrete offense, but the fact remains that criminal forfeiture is limited to the offense of conviction. ${ }^{16}$ As discussed below, forfeiting property derived from or used to commit crimes other than the offense of conviction is one of the reasons prosecutors in the United States need to rely on NCB forfeiture.

In the US as in many countries, if the defendant no longer has the property subject to forfeiture - e.g., because he has spent it, or hidden it, or sent it overseas - the court can enter a value-based judgment, ordering him to pay a sum of money equal to what he personally gained from the

13 Rule 32.2(b)(5), F.R.Crim.P.

14 United States v. Stevenson, 834 F.3d 80 (2nd Cir. 2016).

15 United States v. Capoccia,503 F.3d 103, 109 (2d Cir. 2007).

16 United States v. Capoccia, 503 F.3d 103, 110, 114 ( $2^{\text {nd }}$ Cir. 2007). 
offense. ${ }^{17}$ The entry of such a money judgment is mandatory, ${ }^{18}$ and may be enforced by ordering the defendant to forfeit untainted property of equivalent value as a substitute asset. ${ }^{19}$

There is one other limitation on criminal forfeiture that is somewhat unique to the United States: because the forfeiture is imposed in a criminal proceeding to which only the criminal defendant is a party, property belonging to a third party cannot be forfeited in a criminal case even if it was used to commit the crime for which the defendant was convicted. Indeed, it would be considered a violation of the due process rights of the third party to order the forfeiture of his property in a proceeding in which he was not permitted to participate. Accordingly, once the court enters an order forfeiting property derived from or used to commit a crime, the court must conduct a post-trial ancillary proceeding at which any third party with an interest in the forfeited property may file a claim contesting the forfeiture on the ground that the property belonged to him when it was used to commit the crime, or that he acquired it thereafter as a bona fide purchaser for value. ${ }^{20}$

Accordingly, if the Government wants to seek the forfeiture of property owned by a third party that was used to commit a criminal offense, it must institute an NCB forfeiture action against the property, even if the defendant has been convicted of using that property in a criminal case. ${ }^{21}$

\subsection{NCB Forfeiture Procedure}

NCB forfeiture cases are actions against the property itself, not against the property owner. Persons seeking to contest the forfeiture (known as "claimants") must intervene in the forfeiture case and must show that they have standing to do so. ${ }^{22}$

The custom in the United States is to name the property that is subject to forfeiture in the caption of the case; that is why our NCB cases have names such as United States v. Real Property Located at 475 Martin

17 Honeycutt v. United States, 137 S. Ct. 1626 (2017); United States v. Vampire Nation, 451 F.3d 189, 202 (3d Cir. 2006).

18 United States v. Blackman, 746 F.3d 137, 143 (4th Cir. 2014).

1921 U.S.C. $\S 853($ p).

2021 U.S.C. $\S 853(\mathrm{n})$.

21 United States v. One Red 2003 Hummer H2, 234 F. Supp.3d 415 (W.D.N.Y. 2017) (forfeiting vehicle used by owner's son to transport illegal drugs; civil forfeiture necessary to forfeit interest of third party even though person in possession was charged criminally).

22 United States v. Vazquez-Alvarez,760 F.3d 193, 197 (2 ${ }^{\text {nd }}$ Cir. 2014). 
Laneor United States v. One Red 2003 Hummer H2that some may consider odd or unusual. Naming the property as the subject of the proceeding, however, does not mean that the Government believes property has done something wrong. Rather, NCB forfeiture is simply a procedural device an in rem action -- designed to get everyone with an interest in the property in the courtroom at the same time..$^{23}$

For example, if the Government believes that the property located at 475 Martin Lane or the Red Hummer H2 is subject to forfeiture (as the proceeds of a crime or as property used to commit one), it would name the property as the subject of the forfeiture action and invite anyone with an interest in the property - the titled owner, his spouse, a lien holder, a person with a leasehold interest - to file a claim and contest the forfeiture in a single proceeding. This is a far more efficient process than would ensue if the Government were required to file a separate $\mathrm{NCB}$ forfeiture action against each of those potential claimants individually.

For the United States, this is not a new concept. To the contrary, it was developed in the Eighteenth Century as a way of recovering property from pirates and slave traffickers whose vessels and cargo could be seized, but who remained outside of the jurisdiction of the US and its courts. So, if the Government seized the pirate ship and all of its cargo but could not lay hands on the ship owner, it brought an NCB forfeiture action against the ship and invited the pirate to come into court to oppose the action. If he refused to do so, he could not be prosecuted criminally; there is no possibility of conviction in abstentiain the United States. But the Government could recover his property.

Federal prosecutors now use NCB forfeiture in all manner of cases, from drugs, to fraud, to corruption, to virtually every other type of crime for which forfeiture is authorized. And to those who ask if it is still used against pirates and slave traffickers the answer is yes, we still have pirates, we just call them terrorists; and we still have slave traffickers, we just call them human traffickers, or persons involved in the sex trade.

The important thing to know about civil or NCB forfeiture is this:it doesnot require a conviction or even a criminal case; the forfeiture action may be commenced before a related criminal case is filed, while one is pending, after one is concluded, or if there is no related criminal case at all. But in all events the Government must prove two things: that a crime was committed, and that the property was derived from or used to commit that crime.

23 United States v. Ursery, 518 U.S. 267, 295-96 (1996) (Kennedy, J. concurring). 
As in a criminal forfeiture case, the Government must establish the second element - the nexus between the property and the offense - by a balance of the probabilities. But in contrast to a criminal case, it need only establish the first element - that a criminal offense was committed - by a balance of the probabilities as well, not beyond a reasonable doubt. ${ }^{24}$

In the case of facilitating property, the owner of the property does not have to be the wrongdoer; someone else may have used his property to commit the crime, and if so, the property may be subject to forfeiture even though the owner has not been charged with any criminal offense. The owner, however, would have the right to intervene in the case and assert an innocent owner defense. That is, once the Government establishes that a crime was committed, and that the property was used to commit the crime, the owner could assert that he did not know that his property was being used in that way, or that he took all reasonable steps to prevent it. And if the third party establishes that defense by a balance of the probabilities, he will prevail. ${ }^{25}$

So, for example, if someone uses his wife's car to commit a crime, and the wife knew all about it and let it happen, the Government could forfeit the car in an NCB forfeiture action without having to charge the wife with any crime. But if she did not know that her car was being used to commit a crime, she would have an innocent owner defense, and would have the right to recover her attorney's fees if she prevailed. ${ }^{26}$

The procedure in an NCB forfeiture action may be summarized as follows: ${ }^{27}$ the Government commences the action by seizing the property (generally with a judicial warrant) and filing a complaint setting forth the basis for its belief that the property is subject to forfeiture. It must send a copy of the complaint to any person who appears to have a legal interest in the property and must give such persons time to file a claim contesting the forfeiture.

If a claim is filed, the parties - the Government and the claimant(s) - engage in civil discovery; that is, they may make reciprocal demands on each other to produce relevant evidence and to respond to interrogatories.

24 Prior to the enactment of the Civil Asset Forfeiture Reform Act of 2000 (CAFRA), the burden was on the claimant to prove that the property was not subject to forfeiture. CAFRA, however, abolished the reverse burden of proof and placed the burden of establishing the forfeitability of the property on the Government. 18 U.S.C. $\$ 983(c)(1)$.

2518 U.S.C. $\S 983(\mathrm{~d})$.

2628 U.S.C. $\S 2465($ b).

27 The procedures governing civil forfeiture practice are set forth in Supplemental Rule G of the F.R. Civ.P. and 18 U.S.C. $§ 983(a)$. 
At the end of the discovery process, the parties may file dispositive motions. For example, the Government may challenge the claimant's standing to contest the forfeiture or move for summary judgment based on the undisputed facts. Or the claimant may move to suppress evidence that was illegally seized, move to dismiss the complaint, or file his own crossmotion for summary judgment.

If no dispositive motions are granted, the case goes to trial before a federal judge. If either party so requests, the forfeitability of the property, as well as any innocent owner defense, must be determined by a jury. If the Government prevails - i.e., if it establishes both that a crime was committed and that the property was derived from or used to commit that crime - and the claimant does not establish an innocent owner defense, the court will enter an order transferring title to the property to the Government.

\subsection{When Does the Government Elect to Use NCB Forfeiture?}

If NCB forfeiture is such a powerful tool, why doesn't the Government forfeit everything civilly instead of including it as part of a criminal case? Or asked differently, how does the prosecutor decide whether to bring the case criminally as part of a criminal prosecution, or separately in an NCB forfeiture action?

First, it may be a lot of extra work for the prosecutor to file a separate NCB forfeiture action if the property can be recovered as part of the defendant's sentence in a related criminal case. Also, NCB forfeiture has a serious limitation.

Recall the second requirement: that the Government must prove the property was derived from or used to commit the crime. Because it is an actionin rem against specific property, there are no substitute assets or value-based judgments in an NCB forfeiture case. So, if the Government cannot establish the connection between the asset and the underlying crime, there can be no forfeiture.In particular, in cases where the money has already been spent, or cannot be found, NCB forfeiture is not option.

For both of these reasons, federal prosecutors in the United States generally reserve NCB forfeiture for cases where the criminal prosecution is not possible or not appropriate, or where a criminal case is not ready to indict. Nevertheless, that leaves the following eleven situations in which NCB forfeiture is likely to be the prosecutor's vehicle for recovering criminally-tainted property. 
1. When the property is seized but the forfeiture is unopposed: it is commonplace in the United States for a defendant accused of a criminal offense to waive his right to contest the forfeiture of the money, firearm or other property seized from his possession at the time of his arrest. In such cases, the Government is able to dispose of the property quickly in an unopposed NCB forfeiture action (referred to as "administrative forfeiture" in the case law) rather than delaying the disposition of the property until the conclusion of the defendant's criminal trial.

2. When the wrongdoer is dead or is incompetent to stand trial: there can be no criminal forfeiture if the defendant cannot be brought to trial. Thus, in many cases, the Government files an NCB forfeiture action because the defendant has died but the property remains subject to forfeiture. ${ }^{28}$ The best-known example of this involved former Enron executive Kenneth Lay who died before his criminal conviction and forfeiture judgment became final, and whose criminally-derived assets therefore had to be forfeited in a subsequently-filed NCB forfeiture case. ${ }^{29}$

3. When the defendant is a fugitive or a foreign national beyond jurisdiction of the United States: criminal forfeiture is also not an option if the defendant is a foreign national who commits a crime in a foreign country but launders or invests the proceeds in the United States. In such cases, NCB forfeiture is the only available remedy.

Examples of this abound. In a series of cases, federal prosecutors have used NCB forfeiture to recover the assets of Gen. Sani Abacha who used banks in the US to launder billions of dollars stolen during his time as the military ruler in Nigeria, of Kim Dotcom who stole millions of dollars of intellectual property from copyright holders in the US while residing in New Zealand, and of Russian organized criminals who stole over \$200 million from the Russian treasury and invested some of the money in property in New York. ${ }^{30}$

28 SeeUnited States v. $\$ 120,751.00,102$ F.3d 342, 344 (8th Cir. 1996) (civil forfeiture does not abate upon the death of the owner).

29 United States v. Lay, 456 F. Supp. 2d 869, 874 (S.D. Tex. 2006).

30 United States v. All Assets Held in Account Number 80020796, 83 F. Supp.3d 360 (D.D.C. 2015) ( $\$ 2$ billion stolen from Nigeria by Gen. Abacha, laundered through U.S. banks, and deposited in Jersey, France and the UK); United States v. All Assets Listed in Attachment A (MegaUpload, Ltd.), $89 \mathrm{~F}$. Supp.3d 813 (E.D. Va. 2015) (funds derived from theft of U.S. intellectual property on internet website managed from New Zealand); United States v. Prevezon Holdings, Ltd., 251 F.Supp.3d 684 (S.D.N.Y. 2017) (timing and pattern of transactions may serve as circumstantial evidence that the money moving through a complex series of transactions is traceable to the original SUA). 
Similarly, criminal forfeiture is not an option if the defendant commits the crime in the United States but then flees to another jurisdiction, leaving his forfeitable property behind. In such cases, the Government typically files an NCB forfeiture action against the property and then invokes the fugitive disentitlement doctrine, 28 U.S.C. $\S 2466$, to bar the fugitive from contesting the forfeiture until and unless he surrenders to face the criminal charges. ${ }^{31}$

4. When the statute of limitations has run on the criminal case: in the United States, a criminal prosecution generally must be commenced within five years of the date of the offense. NCB forfeiture actions also have a fiveyear limitations period, but the time runs from the date of the discovery of the offense, not the date when the offense occurred. ${ }^{32}$ So, there are cases in which a criminal prosecution is not viable because the statute of limitations has expired but NCB forfeiture remains available as a means of recovering the criminally-tainted property.

5. When tainted property has been recovered but law enforcement does not know who committed the crime giving rise to the forfeiture: it is not uncommon for law enforcement agents to recover property that is demonstrably connected to a criminal offense even though it is not possible to determine who the perpetrator of the offense happens to be. For example, if weapons, flight simulators, contraband electronics, or money is intercepted while on the way to a country designated as a supporter of terrorism, the property is subject to forfeiture even though it is unclear who the exporter or recipient of the property might be, and there is therefore no one to prosecute and no one to convict in a criminal case.

The same is true if bundles of money wrapped in rubber bands and tainted with drug residue are seized from a courier who is unable (or unwilling) to identify the owner of the property, or if a cultural artifact or work of art is recovered from an auction house but no one knows who stole it or imported it. ${ }^{33}$

In all of those instances, a non-conviction-based order will reach the

31 United States v. Real Property Known As 7208 East $65^{\text {th }}$ Pl., 185 F. Supp.3d 1288 (N.D. Okla. 2016) (defendant indicted for selling worthless medicine to terminally ill cancer patients flees to Mexico).

3219 U.S.C. § 1621; United States v. Real Property 874 Gartel Drive, 79 F.3d 918, 922 (9th Cir. 1996).

33 United States v. Eighteenth Century Peruvian Oil on Canvas, 597 F. Supp.2d 618, 623 (E.D. Va. 2009) (religious oil paintings imported from Peru in violation of the Conventional on Cultural Property Implementation Act are subject to forfeiture under 19 U.S.C. § 2609); 
property and force the property owner to come forward to contest the forfeiture proceeding.

6. When the defendant is convicted of a crime different from the one giving rise to the forfeiture: as mentioned earlier, the federal courts in the United States have not fully adopted the concept of 'extended confiscation' whereby a conviction for a given offense will give rise to a forfeiture order directed at the proceeds of all other crimes that the same defendant has committed. To the contrary, because criminal forfeiture is regarded as part of the defendant's sentence relating to the commission of a given offense, only property connected to the commission of that offense is subject to criminal forfeiture. In those cases, the Government must bring a nonconviction-based forfeiture action to recover any property involved in other offenses.

7. When there is no federal criminal case because the defendant has already been convicted in a state or foreign or tribal court: suppose a crime was committed outside of the United States and the perpetrator has been convicted in the foreign country, but the property is now in the United States and the foreign country has not (for whatever reason) been able to obtain a confiscation order that the US is able to enforce. In that case, even if the US were able to lay hands on the defendant it might be unnecessary - and be considered a waste of judicial resources - to prosecute him a second time for crimes that he committed in the US just to recover his USbased criminal assets. The same could true regarding a federal criminal prosecution for an offense for which the defendant has already been convicted in a state court. ${ }^{34}$

In both instances, filing an NCB forfeiture action allows the Government to recover the property in federal court without having to bring an unnecessary criminal prosecution.

8. When there is no criminal case because the interests of justice do not require a conviction: there are many times when the Government chooses not to bring a criminal case even though there was a clear violation of the criminal lawbecause the interests of justice do not require a conviction. This is called the exercise of prosecutorial discretion.

34 United States v. \$7,679.00 U.S. Currency, 2015 WL 7571910 (W.D.N.Y. Nov. 24, 2015) (defendant pleads guilty to state drug offense and federal agency adopts seizure for civil forfeiture under federal law). 
Suppose, for example, a convicted felon has persuaded his 70-year old mother to purchase a firearm on his behalf, in a situation where both of them know that it is a violation of federal law for a convicted felon to possess such a weapon. And suppose the mother not only buys the firearm but lies on the required document when asked if she is buying it for herself or for a third party.

In that case, the mother has clearly violated federal law and would be subject to criminal prosecution, but faced with the choice between doing nothing (and allowing the felon to retain the weapon) and bringing criminal charges against the aged woman, the Government might decide that confiscating the weapon pursuant to a non-conviction-based forfeiture order is the right thing to do. ${ }^{35}$

9. When the evidence is insufficient to prove that the defendant committed the offense beyond a reasonable doubt: in both criminal and NCB forfeiture cases, the Government bears the burden of proving the connection between the property and the criminal offense by a balance of the probabilities. The same standard applies in NCB cases to the Government's proof that a crime was committed, but in criminal cases the Government must prove not only that a crime was committed, but that a particular defendant committed the crime beyond a reasonable doubt. When the Government cannot meet that higher standard in a criminal case, it may resort to NCB forfeiture as the appropriate means of recovering the property.

10. When the defendant uses someone else's property to commit the crime and that person is not an innocent owner: as mentioned earlier, it is not uncommon for a defendant to use another person's property to commit a criminal offense. For example, he may have laundered his money through a third party's business, robbed a bank with a third party's gun, or distributed drugs using a third party's airplane. In such cases, NCB forfeiture makes it possible to forfeit the third party's interest in the property without having to charge the third party with a crime. Indeed, because federal law in the United States does not permit the forfeiture of a third party's property in a criminal case even if the person is not an innocent owner, NCB forfeiture is the only way for the Government to recover the property without charging

35 United States v. 6 Firearms, Accessories and Ammunition, 2015 WL 4660126 (W.D. Wash. Aug. $5,2015)$. 
the third party with a criminal offense.

In such cases, the third party would have the right to intervene and defend his property interest by contesting the Government's proof on the merits and/or by asserting that he is an innocent owner of the property.

11. When the criminal investigation will take a long time, and there is a danger that the property will disappear: finally, federal prosecutors may commence an NCB forfeiture action as a means of freezing forfeitable property while a criminal investigation is underway but before the Government is ready to file formal criminal charges. In such cases, which are common, the Government commences the forfeiture action but then asks the court to stay the prosecution of the case to avoid having to disclose the details of the criminal investigation in the course of civil discovery. ${ }^{36}$

At the same time, the property owner is highly likely to agree to the stay, or to seek a stay on his own behalf, to avoid having to choose between waiving his Fifth Amendment right against self-incrimination and failing to give evidence in defense of his property. ${ }^{37}$

Indeed, beyond the United States, this turns out to be a key reason for enacting NCB forfeiture provisions in civil law jurisdictions, where the investigation of politically exposed persons involved in corruption cases can take years to resolve.

\subsection{Constitutional Safeguards}

While NCB forfeiture does not require a criminal conviction, most of the safeguards for individual liberty that apply in criminal cases apply equally in NCB forfeiture cases. Where exceptions exist, the rationale is that the protections that apply when someone's liberty is at stake have historically not applied when the only issue is the imposition of a monetary penalty or the loss of property.

In both criminal and NCB forfeiture cases, the property owner enjoys the right to have the forfeitability of his property determined by a jury, and to have the Government establish the nexus between the property and the offense by a balance of the probabilities. ${ }^{38}$ In both cases, the property owner also has the right to move to suppress evidence that was obtained

3618 U.S.C. $\S 981(\mathrm{~g})(1)$.

3718 U.S.C. $\S 981(\mathrm{~g})(2)$.

38 Rule G(9), F.R.Civ.P., Rule 32.2(b)(5), F.R.Crim.P., 18 U.S.C. § 983(c)(1) (placing the burden of proof on the Government in civil forfeiture cases). 
in violation of his Fourth Amendment protection against unreasonable searches and seizures. ${ }^{39}$ And in both cases, the forfeiture is limited by the Excessive Fines Clause of the Eighth Amendment which bars forfeitures that are "gross disproportional to the gravity of the offense." 40

In addition, both legislative schemes protect the rights of third parties by allowing them to intervene in the forfeiture case and to assert that the property belongs to them (which is a complete defense to criminal forfeiture) or that it belongs to them and they qualify as innocent owners (in NCB cases). In both cases, the burden of proof is on the third party to establish that he is entitled to have his property exempted from forfeiture. ${ }^{41}$

Finally, in both cases, the party that fails to prevail at the trial level has the right to appeal.

In other instances, the protections afforded in NCB cases are actually greater than theyare in criminal cases. For example, the scope of civil discovery in NCB cases is much broader than the scope of criminal discovery. Thus, in NCB cases, the claimant / property owner can force the Government to divulge evidence and produce witnesses in advance of trial that the Government would not be required to divulge or produce in a criminal case. ${ }^{42}$

Also, while hearsay is admissible in criminal forfeiture cases to establish the forfeitability of the property after the defendant is convicted (because the forfeiture proceeding is deemed to be part of the sentencing process), in NCB cases the Government must establish both elements that a crime occurred and that the property was derived from or used to commit the crime - with admissible non-hearsay evidence. ${ }^{43}$

Furthermore, a variety of due process protections apply in $\mathrm{NCB}$ cases that have no counterpart in criminal cases. For example, the Government must commence an NCB forfeiture proceeding by providing 39 Rule G(8)(a), F.R.Civ.P. (making the exclusionary rule applicable to civil forfeiture cases).

40 United States v. Cheeseman, 600 F.3d 270, 282 (3d Cir. 2010) (the Excessive Fines Clause applies to both criminal and civil forfeiture); 18 U.S.C. $§ 983$ (g) (making the Excessive Fines Clause applicable to civil forfeiture by statute).

4121 U.S.C. § 853(n) (addressing third party rights in criminal cases); 18 U.S.C. § 983(d) (creating an innocent owner defense in civil forfeiture cases).

42 United States v. Approximately \$69,577 in U.S. Currency, 2009 WL 1404690, *3 (N.D. Cal. May 19,2009 ) (Government is entitled to stay if providing discovery to defendant's family members in the civil case would provide defendant with earlier and broader discovery than he could obtain in his criminal case).

43 Compare United States v. Ali, 619 F.3d 713, 720 (7th Cir. 2010) (hearsay admissible in criminal forfeiture proceedings) with United States v. $\$ 92,203.00$ in U.S. Currency, 537 F.3d 504, 510 (5th Cir. 2008) (hearsay not admissible in civil forfeiture cases). 
notice to anyone with a potential interest in the property in a manner that is likely to achieve actual notice. ${ }^{44}$ Moreover, the Government must commence its action within a fixed time following the seizure of the property and the demand by the property owner for its return.

There are, of course, instances in which the safeguards in criminal cases are greater than those in NCB cases, the most important of which concerns the burden of proof. While the Government bears the burden of proof in both cases, and while it is required to establish the nexus between the property and the offense by the same standard in both cases, in criminal cases the Government must establish that a crime was committed, and was committed by a particular person, beyond a reasonable doubt, whereas in NCB cases it need only prove that a crime was committed by someone by a balance of the probabilities. This reflects the historical view in the United States that the higher standard must be met when a person's life or liberty is at stake, but that the lower standard is sufficient when the litigation concerns only the possibility of a monetary penalty or the loss of a property interest. ${ }^{45}$

Criminal and NCB cases also differ with respect to the application of the Fifth Amendment right against self-incrimination. While the defendant / claimant retains the right to refuse to be a witness against himself in both cases, the consequences of invoking that right differ depending on the nature of the proceeding. In criminal cases, the Government can make no reference to, nor draw any adverse inference from, the defendant's invocation of his Fifth Amendment right to remain silent. In contrast, in NCB cases, if a claimant invokes that right, the court may draw an adverse inference from his silence. ${ }^{46}$

Moreover, a claimant who refuses to answer any questions regarding his relationship to the property in an NCB forfeiture case may find that he is unable to satisfy his burden of establishing standing to contest the forfeiture. ${ }^{47}$

44 Dusenbery v. United States, 534 U.S. 161, 167 (2002).

45 United States v. \$114,700.00 in U.S. Currency, 2017 WL 6205529 (D. Col. Dec. 8, 2017) (Report and Recommendation) (rejecting due process challenge to the preponderance standard; civil forfeiture serves an important Government purpose, there is a clear rationale to the preponderance standard, and the other protections in CAFRA are adequate to ensure property is not taken without due process; beyond a reasonable doubt is reserved for criminal cases, and clear and convincing applies in extraordinary cases involving deportation, denaturalization and termination of parental rights, not cases involving the loss of money), adopted by the district court, 2018 WL 655040 (D. Col. Feb. 1, 2018). 46 United States v. U.S. Currency in the Amount of \$119,984.00, 304 F.3d 165, 177 (2d Cir. 2002). 47 United States v. \$162,576.00 in U.S. Currency, 2011 WL 5239747, *5-6 (M.D. Ga. Nov. 1, 2011). 
Finally, criminal and NCB cases differ with respect to the application of the Sixth Amendment right to counsel. In neither case may the defendant / claimant use criminally-derived funds to pay for an attorney.$^{48}$ In criminal cases, however, a defendant who is barred from using his property for that purpose is entitled to the appointment of counsel at the Government's expense. In contrast, in NCB cases, a claimant is entitled to the appointment of counsel only if the property subject to forfeiture is his personal residence. ${ }^{49}$ In all other cases, the claimant must await the outcome of the case, and is entitled to be reimbursed for his attorney's fees only if he prevails..$^{50}$

\section{CONCLUSION}

Non-conviction-based forfeiture is viewed as an essential law enforcement tool in the United States that may be employed at the discretion of the prosecutor in appropriate cases, and without which it would be impossible to recover property in a wide variety of cases of great importance, including cases in which the United States is asked to recover property derived from crimes committed in other countries. The due process protections and other safeguards that are integral to criminal proceedings are, for the most part, equally applicable in NCB proceedings and in some instances are surpassed by the protections afforded the parties in NCB cases. In those instances where the criminal safeguards are greater, the safeguards in NCB cases are appropriate in light of the historically greater protection provided when life or liberty, and not solely an interest in property, is at stake.

Artigo recebido em: 10/08/2018. Artigo aceito em: 20/04/2019.

\section{Como citar este artigo (ABNT):}

CASSELLA, S. D. Nature and basic problems of non-conviction-based confiscation in the United States. Veredas do Direito, Belo Horizonte, v.

48 Luis v. United States, 136 S. Ct. 1083 (2016).

4918 U.S.C. $\S 983$ (b).

5028 U.S.C. $\S 2465(b)$. 
16, n. 34, p. 41-65, jan./abr. 2019. Disponível em: <http://www.domhelder. edu.br/revista/index.php/veredas/article/view/1334>. Acesso em: dia mês. ano. 